DOI : $10.14746 /$ rie.2019.13.28

\title{
R. M. Czarny, O. Filipec, M. Grzybowski, Drogi państw nordyc- kich do Unii Europejskiej, Wydawca: Compus, Kielce-Trnava 2018, ss. 168.
}

Publikacja Drogi państw nordyckich do Unii Europejskiej to bardzo interesujące i kompleksowe omówienie kolejnych etapów integracji europejskiej trzech krajów nordyckich - Finlandii, Danii oraz Szwecji1.

Praca, jak wskazują sami Autorzy, reprezentuje prężnie rozwijający się kierunek badań podejmujący próby syntetycznego ujęcia aktywności pewnej grupy czy regionu i jej wyróżników na tle kontynentu europejskiego.

Niewątpliwą osobliwością państw nordyckich, stanowiących przedmiot zainteresowania Autorów książki, oprócz położenia geograficznego i czynników geopolitycznych, jest ich silny związek oparty na wspólnej historii, kulturze, czy wartościach społecznych. Niemniej zajmujące są też drogi wymienionych państw do członkostwa w Unii Europejskiej, co z niezwykłą dbałością przybliżono w omawianej pozycji.

Przedmiotowa publikacja została podzielona na trzy zasadnicze części (a te na rozdziały), w których przedstawiono wieloaspektowe uwarunkowania i kolejne stadia zbliżania się do Europy trójki z pięciu państw europejskiej Północy.

Nietypowym zabiegiem było zamieszczenie w publikacji, oprócz dwóch opracowań polskojęzycznych, fragmentu anglojęzycznego.

Książka poprzedzona została kilkustronicowym Wstępem Ryszarda M. Czarnego, w którym zawarto cenne uwagi terminologiczne dotyczące pojęć „Skandynawia” i „Norden” oraz krótką charakterystykę badanej wspólnoty regionalnej. W dalszej części wprowadzenia zaprezentowano przedmiot, cel pracy oraz uzasadnienie wyboru badanego obszaru. Omówiono również strukturę dzieła, pokrótce zarysowując treść poszczególnych jego części.

W pierwszej z nich, zatytułowanej Finlandia w drodze do Unii Europejskiej, autorstwa Mariana Grzybowskiego, przybliżono pozycję geopolityczną Finlandii po II wojnie światowej i związane z nią trudności w zakresie integracji z krajami Europy Zachodniej. Następnie zwrócono uwagę na kwestię przynależności Finlandii do regionalnej współpracy państw nordyckich oraz debatę przedakcesyjną i ewolucję postaw podmiotów zbiorowych i obywateli po przystąpieniu do struktur unijnych. W dalszej kolejności omówiono instytucjonalne aspekty i następstwa integracji europejskiej, bilans 22-lecia członkostwa oraz kwestię „Wymiaru Północnego” polityki unijnej. Opracowanie uzupełniają zestawienia tabelaryczne.

W drugiej, anglojęzycznej części, pt. Denmark on the way to the European Economic Community (Dania w drodze do Europejskiej Wspólnoty Gospodarczej), przedstawiono analizę zewnętrznych i wewnętrznych sił politycznych mających wpływ na akcesję Danii do zachodnioeuropejskich struktur integracyjnych. Jej autor, Ondřej Filipec, głównym punktem badań uczynił wzajemne relacje Danii z najważniejszymi europejskimi graczami, tj. Wielką Brytanią, Francją oraz Niemcami. Ponadto omówił stanowisko Danii wobec integracji zachodnioeuropejskiej w latach 50. XX w., jak również poruszył kwestie rozczarowania Europejskim Stowarzyszeniem Wolnego Handlu, czy dwóch francuskich weto niweczących proces akcesyjny. Nadto, Autor zwrócił uwagę na wpływ sił politycznych w referendum w sprawie akcesji do Wspólnot Europejskich (przeprowadzonym w 1972 r.) oraz konsekwencje przystąpienia do struktur unijnych.

${ }^{1}$ Do państw europejskiej Północy (Norden), tradycyjnie zaliczane są kraje należące do Rady Nordyckiej: kraje skandynawskie - Szwecja, Norwegia i Dania, a także Islandia, Finlandia oraz terytoria autonomiczne - Grenlandia, Wyspy Owcze i Wyspy Alandzkie. 
W części trzeciej publikacji, pt. Proces akcesji Szwecji do Unii Europejskiej, autorstwa Ryszarda M. Czarnego, ukazano strategię integracji i negocjacje odnośnie do warunków członkostwa. Autor wskazał na prawne aspekty procesu integracji, rolę parlamentu oraz konieczność przygotowania i edukacji administracji. Ponadto omówił przebieg kampanii informacyjnej, która miała na celu dostarczenie wszechstronnej i pełnej informacji odnośnie do procesu integracji, Unii Europejskiej oraz problemów związanych z członkostwem. W końcowym rozdziale Autor przedstawił efekty negocjacji, jak również konsekwencje polityczne i gospodarcze wynikające z akcesji. Na szczególną uwagę zasługuje zamieszczenie Aneksów, które niewątpliwie służą uporządkowaniu i lepszemu zrozumieniu przedstawianych zagadnień, tj. zestawienia: wskaźników obrazujących stan szwedzkiej gospodarki w latach 1995-1997, wpłat Szwecji i zwrotu środków z Unii Europejskiej, najistotniejszych dat dotyczących akcesji Szwecji do struktur unijnych, czy efektów negocjacji (z podziałem na obszary), jak również oświadczenia szwedzkiego Ministra ds. Europejskich i Handlu Zagranicznego, Ulfa Dinkelspiela z 1993 r., oraz głównych tez wystąpienia premiera Görana Perssona z 1999 r.

Publikację wieńczy Zakończenie oraz Noty o Autorach. W Zakończeniu Autorzy jeszcze raz podkreślili wielość powiązań pomiędzy państwami obszaru nordyckiego, wskazując jednocześnie na odmienne drogi uzyskania członkostwa w Unii Europejskiej. Podsumowując, zwrócili uwagę na pojawiającą się koncepcję budowy „nordyckiego bloku w Unii Europejskiej” i przedstawili motywy powstania przedmiotowego opracowania.

Przejrzysta konstrukcja pracy, jak i powtarzalność struktury poszczególnych jej części (podział na rozdziały, podsumowanie, bibliografię) czynią publikację czytelną i spójną.

Szczególnie cenne wydaje się być zastosowanie porządkujących wiedzę zestawień tabelarycznych (część pierwsza i trzecia), wykresów, czy przedstawień graficznych (część druga) oraz aneksów (część trzecia).

Na uwagę zasługuje fakt, że Autorzy w swych opracowaniach wskazali zarówno na aspekty formalno-prawne, polityczne i gospodarcze, jak również kulturowo-społeczne procesów integracyjnych analizowanych państw, znajdując odniesienia także do problemów współczesnych.

W publikacji oparto się na bogatej literaturze przedmiotu - polskiej oraz w dużej mierze zagranicznej (głównie skandynawskiej oraz anglojęzycznej). Jak podkreślano we Wstępie, niezwykle przydatne, oprócz analiz empirycznych, okazały się być prace teoretyczne o charakterze komparatystycznym.

Podkreślić należy, iż na przedmiotową publikację składają się opracowania Autorów będących ekspertami w badanym obszarze, co niewątpliwie czyni ją dziełem szczególnie wartościowym.

Życzeniem Autorów, wyrażonym we Wstepie, było stworzenie kompendium, które poprzez wielość analiz i informacji w nim zawartych ma pogłębić wiedzę o państwach europejskiej Północy i procesach integracyjnych zachodzących na Starym Kontynencie. Niewątpliwie ten cel udało im się zrealizować.

Na zakończenie należy podkreślić, iż omawiana publikacja to bardzo szczegółowe i kompetentne przedstawienie badanego zagadnienia, podejmujące tematykę niezwykle ważką i aktualną. Praca w klarowny i interesujący sposób ukazuje kolejne stadia procesów integracyjnych trójki państw nordyckich. Wskazując przyczyny, warunki i konsekwencje członkostwa w Unii Europejskiej, stanowi idealny łącznik i podstawę dla ujęć komparatystycznych.

ANNA RATAJCZAK

Uniwersytet im. Adama Mickiewicza w Poznaniu 